\title{
THE EFFECT OF MULIA, AR-RUM, SHARIA-COMPLIANT BANK OF INDONESIA'S CERTIFICATE, INFLATION AND BI RATE ON SHARIA PAWNSHOP'S INCOME IN INDONESIA
}

\author{
Ade Sofyan Mulazid1, Nina Astriana2 \\ 1adesofyanmulazid@uinjkt.ac.id,2astriana_n@yahoo.com \\ Universitas Islam Negeri Syarif Hidayatullah Jakarta
}

\begin{abstract}
This research aimed to analyze the effect of Mulia, Ar-Rum, Shariacompliant Bank of Indonesia (sharia-compliant Bank of Indonesia)'s Certificate, Inflation and BI Rate on sharia pawnshop's income in Indonesia during 20152017. Case study being the object of research was PT. Pegadaian (Persero). Secondary data derived from annual report published by Pegadaian (thereafter called Pawnshop). This study employed a multiple regression analysis method. The result of research showed that (1) Mulia financing affected significantly the income of Sharia pawnshop (thereafter, called Sharia pawnshop), (2) Ar-Rum Financing did not affect significantly the income of Sharia Pawnshop, (3) Shariacompliant Bank of Indonesia's Certificate did not affect significantly the income of Sharia pawnshop, and (4) inflation affected significantly the income of Sharia pawnshop and BI Rate affected Sharia pawnshop's income significantly.
\end{abstract}

Keywords: Mulia, Ar-Rum, inflation, BI Rate and Sharia pawnshop

\section{INTRODUCTION}

The development of sharia-based products is getting more prevalent in Indonesia, so is fiduciary product (Rahn). Irianto, operating manager of Sharia pawnshop says that Sharia pawnshop has 500 outlets and contributes to $63 \%$ of sale volume growth until October 2010. Sharia-compliant fiduciary business also increases to $158 \%$ in the end of 2010.1 Pegadian's first-semester financial statement, Pawnshop has 4.390-unit outlets, 8 million customers, and sale volume of 60 trillion throughout Indonesia per June 2017.

Pawnshop is an alternative to get fund and financing needs. In addition to providing fiduciary, electricity and telephone billing, and motor-vehicle and precious metal ownership services, Pawnshop also provides financing for business

1 Febrianur Ibnu Fitroh Sukono Putra, Gemelli Milad Muhammady, Almira Nur Aulia, dinamaika perkembangan pegadaian syariah di Indonesia, (2016, Surakarta: STIKES

Muhammadiyah Pekajangan). Hal. ...

website:http://jurnal.radenfatah.ac.id/index.php/ieconomics 
in Micro-, Small-, and Medium-scale (SME) sector, the payment of which is made in installment manner with pawning or fiduciary system. Fiduciary is an easy and practical loan to meet the fund need using pawning system in the form of gold, diamond, motor vehicle, and electronic appliances.

Ar-Rahn or Ar-Rum financing product for Micro-scale Enterprise is a solution to micro- or small-scale enterprise to get additional capital to develop the business that has been initiated. By making motor vehicle ownership book the collateral, customers who will apply for Ar-Rum product financing will be assessed for their business feasibility, from capital capacity, business type, business capability, collateral, customer character to other aspects needing assessment corresponding to standardization specified by Sharia pawnshop.

Company pays attention to external factor including economic condition such as inflation rate and gold price. Inflation and income of Pawnshop are indictors to analyze the development of sharia-compliant pawning loan distribution with fluctuating inflation rate impacting on the increase in the basic price of productive and consumptive needs.

In addition, high inflation rate will result in unstable economy, slow economic growth, and increased unemployment rate. Then, high volume of money circulating can result in lowered money value, so that Bank of Indonesia (BI) rate will increase. This increase can impact on the increase in Pawnshop's financing rate, thereby lowering the public or particularly the upper-middle customers' interest in choosing Pawnshop's financing distribution in certain period, as they have no urgent fund need.2

BI rate serves as the standard for loan and saving rate for banks or financial institutions throughout Indonesia. Market mechanism serves as interest rate based on auction system. Bank of Indonesia Certificate (Indonesian: Sertifikat Bank Indonesia or SBI) is published by BI as an instrument of open market

2 Titi Widiarti, Sinarti, Pengaruh Pendapatan, Jumlah Nasabah, Dan Tingkat Inflasi Terhadap Penyaluran Kredit Pada Perum Pegadaian Cabang Batam Periode 2008-2012, (2013: t, p), hal... 
operation; this transaction activity conducted by BI along with other banks and parties in money market is a monetary controlling attempt.

In addition to Mulia and Ar-Rum financing constituting internal financing existing in Pawnshop, external factors can also affect Pawnshop's income. It is in line with a study conducted by Arma Safitri (2011) on "The effect of Precious Metal Sale on Sharia pawnshop's increased income". This study found that there was a positive and significant effect of precious metal product sale on Sharia pawnshop's income.

It is also in line with a study conducted by Ade Septevany Dewi (2016) on "The effect of customer number, interest rate, and inflation on loan distribution in Pawnshop". The result of t-test showed that customer number partially affected loan distribution. So, it can be estimated that not only internal factor but also other external factors the writer has added such as SBIS, Inflation, and BI Rate affect Sharia pawnshop's income.

Table 1.1

Sharia pawnshop's Income during 2015-2017

\begin{tabular}{|c|c|c|c|c|c|c|}
\hline Year & $\begin{array}{c}\text { Income } \\
\text { (Trillion) }\end{array}$ & $\begin{array}{c}\text { Mulia } \\
\text { (Billion) }\end{array}$ & $\begin{array}{c}\text { Ar-Rum } \\
\text { (Billion) }\end{array}$ & $\begin{array}{c}\text { SBIS } \\
\text { (Billion) }\end{array}$ & Inflation & $\begin{array}{c}\text { BI } \\
\text { Rate }\end{array}$ \\
\hline 2015 & 6.163 & 38.506 & 388.229 & 8.065 & $6.38 \%$ & $7.52 \%$ \\
\hline 2016 & 6.924 & 113.100 & 530.866 & 8.459 & $3.53 \%$ & $6.5 \%$ \\
\hline 2017 & 7.900 & 105.603 & 658.490 & 11.509 & $3.88 \%$ & $4.25 \%$ \\
\hline
\end{tabular}

Table 1.1 shows that Sharia pawnshop's income experiences increasing trend. It is because Sharia pawnshop's income always grows over years during 2015-2017. Sharia pawnshop's income is 1,163 trillion, Mulia is 38.506 billion, Ar-rum is 388.229 billion, SBIS is 8.065 billion, inflation is $6.38 \%$ and BI Rate is $7.25 \%$ in 2015.

Meanwhile, Sharia pawnshop's income increase by 760.849 billion to 6.924 trillion in 2016, with Mulia income increasing by 113,100 billion, Ar-Rum 
by 530.866 billion, SBIS by 8.459 billion, inflation decreasing very dramatically by $3.53 \%$ and $\mathrm{BI}$ rate of $6.5 \%$.

Then, Sharia pawnshop's income increases continuously by 976.689 billion to 7.900 trillion, with Mulia increasing by 105.603 billion, Ar-Rum by 658.490 billion, SBIS 11.509 billion, inflation increasing to $3.88 \%$ and BI rate of $4.25 \%$.

Considering the elaboration above, the research on the effect of Mulia, Arrum, SBIS, Inflation, and BI Rate on Sharia pawnshop's income in Indonesia is important to follow up. The hypothesis of research states that Mulia, Ar-rum, SBIS, Inflation, and BI Rate affect Sharia pawnshop's income in Indonesia.

\section{LITERATURE REVIEW AND RESEARCH HYPOTHESIS}

\section{Sharia-Compliant Pawning}

Sharia-compliant pawning is to retain one of customers' properties (rahin) as collateral (marhun) over loan or credit (marhun bih) they have received. Thus, the one retaining or receiving pawn (murtahin) gets collateral to retake entire or some of his/her receivables. 3

Linguistically, pawn (al-Rahn) means al-tsubut and al-habs or pledge and guaranty. 4 Others explained that rahn is being reduced or entrapped. In syara' it means covenant the object of which restrains price over some right from which a perfect payment is likely obtained. Generally, pawn is defined as an activity of guaranteeing valuables guaranteed to be redeemed according to the agreement between customers and pawning shop (institution).5

Pawn, according to Muhammad (2003), is some right obtained by moneylender over a moving object. The moving object is given by the borrower or others on his/her name to moneylender. The borrower will authorize the

\footnotetext{
3 Ayunia Isnani, Pegadaian Syariah dan Perkembangannya di Indonesia. (2015: Jakarta: Renaisan). Hal. ...

4 Mulazid, Ade Sofyan. Kedudukan Sistem Pegadaian, Edisi Pertama. (2016: Penerbit Prenadamedia Group: Jakarta). Hal. ...

5 Kasmir, Bank dan Lembaga Keuangan Lainnya, (2004: PT. Rajawali Press, Jakarta).
}

website:http://jurnal.radenfatah.ac.id/index.php/ieconomics 
moneylender to use the moving object that has been submitted to pay the loan completely when the borrower cannot fulfill his/her obligation on due time.

Pawn is some right obtained by moneylender over a moving object given to him/her by another individual or other on behalf of his/her name, and then authorizing the moneylender with cost exception to secure the object pawned (Pandia, 2005).

Sharia pawnshop holds on sharia principle in running its operation. In complying with the sharia principles, sharia pawnshop refers to DSN-MUI's fatwa DSN-MUI No.25/DSN-MUI/III/2002 on June 2002 about Rahn stating that loan by pawning the collateral in the form of rahn is allowed, and DSN-MUI's fatwa No.26/DSN-MUI/III/2002 about Gold Pawn. Meanwhile, in institutional aspect it still refers to Government's regulation No.51 of 2011 about the Change of Perum Pegadaian (Fiduciary Government-Owned Corporation) Legal Entity Form into Incorporation.6 Briefly, elaboration about the difference between Sharia-Compliant and Conventional Pawning Shops can be seen in the table below.

Table 2.1

The Difference between Sharia-Compliant and Conventional Pawning Shops

\begin{tabular}{|c|l|l|}
\hline No & \multicolumn{1}{|c|}{ Sharia Pawnshop } & \multicolumn{1}{c|}{ Conventional Pawnshop } \\
\hline 1. & $\begin{array}{l}\text { Its business activity does not } \\
\text { apply interest system and } \\
\text { rightful object }\end{array}$ & $\begin{array}{l}\text { Its business activity applies interest } \\
\text { rate }\end{array}$ \\
\hline 2. & $\begin{array}{l}\text { The surplus of collateral auction } \\
\text { will be returned }\end{array}$ & $\begin{array}{l}\text { The surplus of collateral auction will } \\
\text { not be returned }\end{array}$ \\
\hline 3. & $\begin{array}{l}\text { Accommodating diverse types } \\
\text { of object }\end{array}$ & $\begin{array}{l}\text { Not accommodating diverse types of } \\
\text { object }\end{array}$ \\
\hline 4. & Supervision conducted by DPS & Not under DPS and DPN-MUI's \\
\hline
\end{tabular}

6 Ibid. Mulazid. Ade Sofyan. Kedudukan Sistem Pegadaian, Edisi Pertama. (2016: Penerbit Prenadamedia Group: Jakarta). Hal. ...

website:http://jurnal.radenfatah.ac.id/index.php/ieconomics 


\begin{tabular}{|c|l|l|}
\hline & and DSN-MUI & supervision \\
\hline 5. & The settlement of dispute is & The settlement of dispute is conducted \\
& conducted by basyarnas and & by Indonesian National Arbitrage \\
& Religion Court & Agency (Indonesian: Badan Arbitrase \\
& & Nasional Indonesia or BANI) and \\
& & General Court \\
\hline
\end{tabular}

From table 2.1, it can be seen that viewed from management and administration aspects, sharia pawnshop is not far different from conventional one. Generally, Sharia pawnshop has principle, function, and objective as same as those of national pawnshop. Even viewed from its operation implementation, Sharia pawnshop (sharia pawnshop) is similar to the conventional one because both of them equally distribute loan based on pawn and fiduciary law. However, although generally there are some similarities, Sharia pawnshop is different from the conventional one, particularly in the principle itself.7

\section{Hypothesis}

Hypothesis is usually defined as a relationship estimated logically between two or more variables expressed in the form of testable statement. Considering the objective of research to be achieved, the hypotheses formulated in this research are as follows:

1. Partial Hypothesis
A. Mulia Variable

$\mathrm{H}_{0}$ : Mulia variable does not affect sharia pawnshop's income in Indonesia.

$\mathrm{H}_{1}$ : Mulia variable affects sharia pawnshop's income in Indonesia.

B. Ar-Rum Variable

$\mathrm{H}_{0}$ : Ar-Rum variable does not affect sharia pawnshop's income in Indonesia.

H1: Ar-Rum variable affects sharia pawnshop's income in Indonesia.

C. Sharia-compliant Bank of Indonesia's Certificate (SBIS) Variable

7 Ibid.

website:http://jurnal.radenfatah.ac.id/index.php/ieconomics 
Ho: SBIS variable does not affect sharia pawnshop's income in Indonesia.

H1: SBIS variable affects sharia pawnshop's income in Indonesia.

D. Inflation Variable

$\mathrm{H}_{0}$ : Inflation variable does not affect sharia pawnshop's income in Indonesia.

H1: Inflation variable affects sharia pawnshop's income in Indonesia.

E. BI Rate Variable

$\mathrm{H}_{0}$ : BI Rate variable does not affect sharia pawnshop's income in Indonesia.

$\mathrm{H}_{1}$ : BI Rate variable affects sharia pawnshop's income in Indonesia.

2. Simultaneous Hypothesis

$\mathrm{H}_{0}$ : Mulia, Ar-Rum, SBIS, Inflation and BI Rate do not affect sharia pawnshop's income in Indonesia.

H1: Mulia, Ar-Rum, SBIS, Inflation and BI Rate affect sharia pawnshop's income in Indonesia.

\section{METHOD}

This research employed quantitative method, the one based on positivism philosophy. The research was used in studying research sample and population; the sampling technique employed was random sampling one. Meanwhile, data collection was carried out by using research instrument and data analysis was carried out qualitative or by testing the hypothesis specified before.

Operational data used in this research was secondary one, time series data. Entire data of research was observed in the period of January 2015 -December 2017 released by Annual Report of Pawnshop, Bank of Indonesia, and OJK. The research method employed was historical one that was causal-distributive in nature, meaning that the research was conducted to analyze previous condition and showed the direction of relationship between independent variables (Mulia, Ar-Rum, SBIS, Inflation, BI Rate) and dependent variable (Sharia Pawnshop's Income). 
This study is intended to explain the strength and the direction of the effect of independent/explanatory variable on dependent variable. The method of analyzing data used in this study was a multiple regression one.

$$
\mathbf{Y}=\alpha+\boldsymbol{\beta}_{1} \mathbf{X}_{1}+\boldsymbol{\beta}_{2} \mathbf{X}_{2}+\ldots \ldots . .+\boldsymbol{\beta}_{\mathrm{n}} \mathbf{X}_{\mathrm{n}}+\mathrm{e}
$$

\section{Where:}

$$
\begin{aligned}
& \mathrm{Y}=\text { Dependent variable (projected value) } \\
& \alpha=\text { Intercept (constant) } \\
& \beta_{1}=\text { Coefficient of Regression for } \mathrm{X}_{1} \\
& \beta_{2}=\text { Coefficient of Regression for } \mathrm{X}_{2} \\
& \beta_{\mathrm{n}}=\text { Coefficient of Regression for } \mathrm{X}_{\mathrm{n}} \\
& \mathrm{X}_{1}=\text { First independent variable } \\
& \mathrm{X}_{2}=\text { Second independent variable } \\
& \mathrm{X}_{\mathrm{n}}=\text { nth independent variable } \\
& \mathrm{e} \quad=\text { Error terms (variable excluded from the model not affecting dependent } \\
& \text { variable or called residual variable). }
\end{aligned}
$$

\section{RESULT}

\section{1) Normality Test}

The first statistic analysis used in analyzing data is normality test. This test is intended to see whether or not independent and dependent variables have normal distribution. The way of detecting normality is to use data (point) on diagonal axis and graphic. The rationale of decision making is that when the data is distributed around diagonal line, regression model fulfils normality assumption and vice versa. 8

Normality test is conducted using statistic analysis with graphic analysis and Kolmogorov-Smirnov (K-S) non-parametric statistical tests with SPSS 20 help. The result of normality test is illustrated in figure below.

8 Ghozali, Imam. Aplikasi Analisis Multivariet dengan Program IBM SPSS 20, (Th.: Universitas Diponogoro, Semarang). Hal. ...

website:http://jurnal.radenfatah.ac.id/index.php/ieconomics 


\section{Figure 4.1}

Histogram

Histogram

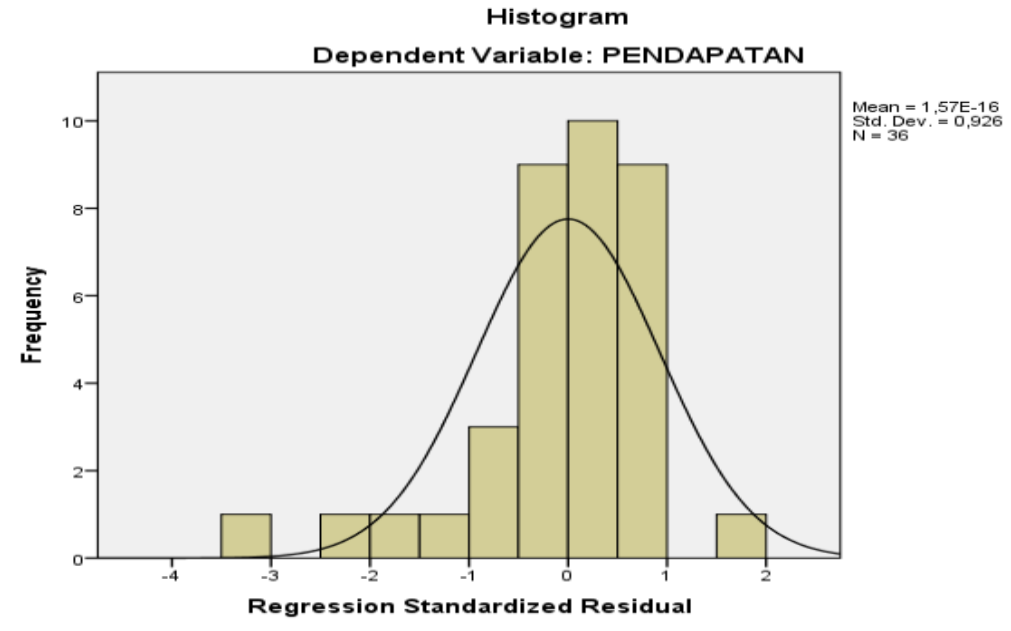

Source: Result of Data Processing

The output of histogram as illustrated in figure 4.1 shows that the distribution of data in Regression Residual histogram creates a curve like a curve having balanced sides, so that residual value is considered as normal or the data is distributed normally.

However, Ghozali says that seeing the histogram only can be misleading, particularly for the small size of sample. The most reliable method is to see Normal Probability Plot comparing cumulative and normal distributions. Normal distribution will create a diagonal linear line and residual data plotting will be compared with diagonal line. Meanwhile, considering the graphic aspect, the result of normality test is illustrated in figure of P-p plot below.

\section{Figure 4.2}

\section{P-Plot Graph}

website:http://jurnal.radenfatah.ac.id/index.php/ieconomics 




The result of P-plot graph in figure 4.2 above shows that the data (points) is distributed around diagonal line and the distribution follows the direction of diagonal line. Thus, it can be concluded that from P-plot graphic analysis, it can be seen that standardized residual value has normal distribution, or in other words, fulfils normality assumption.

\section{2) Multicollinearity Test}

Furthermore, a multiple-regression model assumption to be considered is to find out whether or not there is a multicollinearity phenomenon in the table, meaning there is a perfect or nearly perfect relationship between independent variables. To examine whether or not there is a relationship between independent variables, Variance Inflation Factor (VIF) and Tolerance are used. The criterion used to make decision concerning whether or not there is multicollinearity is that VIF value ranges between 1 and 10 and tolerance value is more than 0.10 and close to 1 . The result of multicollinearity test is presented in Table below.

Table 4.3

Multicollinearity Test

Coeffiecientsa

\begin{tabular}{|l|l|c|}
\hline \multirow{2}{*}{ Model } & \multicolumn{2}{|c|}{ Collinearity statistics } \\
\cline { 2 - 3 } & Tolerance & VIF \\
\hline
\end{tabular}

website:http://jurnal.radenfatah.ac.id/index.php/ieconomics 


\begin{tabular}{|l|c|c|}
\hline (constant) & & \\
Ln_Mulia &, 816 & 1,225 \\
Ln_Ar-Rum &, 500 & 1,999 \\
Ln_SBIS & & 3,554 \\
Inflation &, 281 & 2,076 \\
BI Rate &, 482 & \\
& & \\
&, 146 & \\
& & \\
\hline
\end{tabular}

From the output of multicollinearity test as shown in the table of coefficients above, it can be seen that tolerance value is $0.816(0.816>0.10)$ for Mulia, $0.500(0.500>0.10)$ for Ar-Rum, $0.281(0.281>0.10)$ for Sharia-compliant Bank of Indonesia's Certificate (SBIS), 0.482 (0.482>0.10) for inflation, and $0.146(0.146>0.10)$ for BI Rate.

Meanwhile table of Coefficient above also shows that Variance Inflation Factor (VIF) is $1.225(1.225<10)$ for Mulia, $1.999(1.999<10)$ for Ar-Rum, 3.554 $(3.554<10)$ for Sharia-compliant Bank of Indonesia's Certificate (SBIS), 2.076 $(2.076<10)$ for inflation, and $6.076(6.076<10)$.

In conclusion, the result of tolerance is not less than 0.10 and variance inflation factor (VIF) value is not more than 10, indicating that Mulia, Ar-Rum, SBIS, Inflation and BI Rate variables do not show multicollinearity symptoms.

\section{3) Heteroscedasticity Test}

Heteroscedasticity test aims to examine whether or not in regression model there is variance of residual between one observation and another. If variance of residual is constant from one observation to another, it is called Homoscedasticity and if it is inconstant or fluctuating, it is called Heteroscedasticity. The good regression model is Homoscedasticity rather than Heteroscedasticity (Ghozali, 
2012). The result of Heteroscedasticity using graphic analysis is illustrated using scatterplot in figure below.

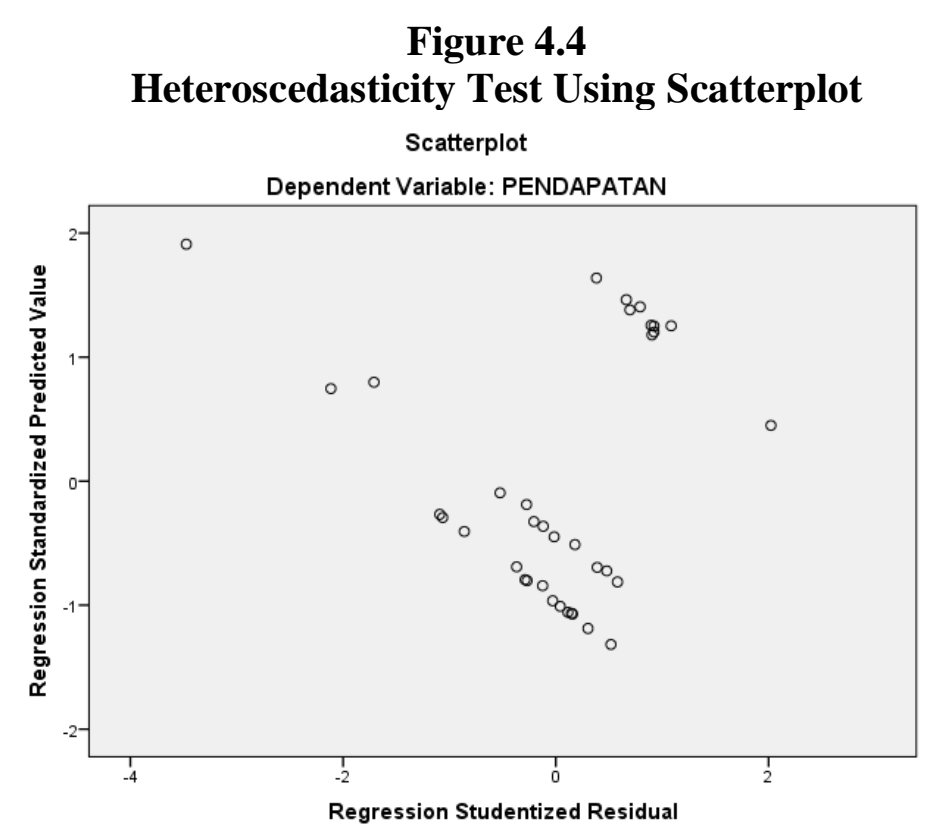

The output of Heteroscedasticity in table 4.4 above, it can be seen that data distribution is around zero point and spreads randomly or does not create a clear certain pattern. Thus, it can be concluded that heteroscedasticity occurs in regression pattern, so that regression model is feasible to use.

\section{4) Autocorrelation Test}

Autocorrelation test aims to find out whether or not there is a correlation between the members of time series or cross section. Classical assumption autocorrelation test is conducted using Durbin-Watson.

Table 4.5

Autocorrelation Test

Model Summaryb

\begin{tabular}{|l|c|r|r|r|l|}
\hline Model & $R$ & $R$ Square & $\begin{array}{c}\text { Adjusted R } \\
\text { Square }\end{array}$ & $\begin{array}{c}\text { Std. Error of the } \\
\text { Estimate }\end{array}$ & $\begin{array}{l}\text { Durbin - } \\
\text { Watson }\end{array}$ \\
\hline 1 &, $835 \mathrm{a}$ &, 697 &, 646 & $2,02247 \mathrm{E}+15$ & 1,690 \\
\hline
\end{tabular}

a. Predictors: (Constant), BI_Rate, Ln_Arrum, Ln_Mulia, Ln_SBIS, Inflation

b. Dependent Variable: Ln_Income

website:http://jurnal.radenfatah.ac.id/index.php/ieconomics 
Table 4.5 shows Durbin-Watson value of 1.690. It indicates that there is no autocorrelation because DW test values ranges between -2 and +2 , so that it can be concluded that there is neither positive nor negative autocorrelation in the regression model developed in this study.

\section{5) Partial (t)Test}

This t-statistic test aims to reveal the extent to which independent variables of Mulia, Ar-Rum, SBIS, Inflation and BI Rate partially explain independent variable of Sharia Pawnshop's income, tested at significant level less than 0.05 (Ghozali, 2013). To find out it, t-test is conducted by comparing t statistic with $t$ table values. T-table value is obtained with degree of freedom (df)df $=\alpha:(n-k)$ where $\alpha$ is the significance level used, $\mathrm{n}$ is observation number (sample size) and $\mathrm{k}$ is number of independent and dependent variables. The rationale of decision making is that if $\mathrm{t}$ statistic $>\mathrm{t}$ table, $\mathrm{H}_{0}$ is not supported, meaning that $\mathrm{X}_{1}$ affects significantly the dependent variable, and vice versa (if $\mathrm{t}$ statistic $<\mathrm{t}$ table, $\mathrm{H}_{0}$ is supported, meaning that $\mathrm{X}_{1}$ does not affect significantly the dependent variable). The result of t-test is presented in table 4.6.

Table 4.6

Partial Test (t)

Coefficientsa

\begin{tabular}{||l|r|r|r|r|}
\hline \multirow{2}{*}{ Model } & \multicolumn{2}{|c|}{ Unstandardized Coefficients } & \multicolumn{1}{c|}{} \\
\cline { 2 - 3 } (Constant) & \multicolumn{1}{|c|}{ B } & \multicolumn{1}{c|}{ Std. Error } & \multicolumn{1}{c|}{ Sig. } \\
Ln_Mulia & $-2,910 \mathrm{E}-061$ &, 099 & 1,000 &, 241 \\
Ln_Arrum &, 330 &, 111 & 2,963 &, 006 \\
Ln_SBIS &,- 142 &, 142 &,- 487 &, 630 \\
Inflation &,- 166 &, 190 &,- 876 &, 388 \\
BI_Rate &, 974 &, 145 & 6,721 &, 000 \\
\hline
\end{tabular}

Dependent Variable: Sharia Pawnshop's Income

The result of partial test on the effect of independent variables on Sharia Pawnshop's income as shown in table 4.6 is explained below.

a) The effect of t-statistic for Mulia on Sharia Pawnshop's Income 
Table 4.6 shows that Mulia variable statistically shows significant output with value less than $\alpha(0.006<0.05)$. Meanwhile, $\mathrm{t}$-statistic value is 2.963 and $\mathrm{t}$ table is $1.6973(\mathrm{df}(\mathrm{n}-\mathrm{k}) 36-6=30, \alpha=0.05)$. Thus, $\mathrm{t}$ statistic $>\mathrm{t}$ table (2.963>1.6973) meaning that $\mathrm{H}_{0}$ is not supported and $\mathrm{H}_{1}$ is supported, so that it can be concluded that Mulia variable partially affects Income significantly.

b) The effect of t-statistic for Ar-Rum on Sharia Pawnshop's income.

Table 4.6 shows that Ar-Rum variable statistically shows insignificant output with value more than $\alpha(0.006>0.05)$. Meanwhile, t-statistic value is -.487 and $\mathrm{t}$-table is $1.6973(\mathrm{df}(\mathrm{n}-\mathrm{k}) 36-6=30, \alpha=0.05)$. Thus, $\mathrm{t}$ statistic $<\mathrm{t}$ table (2.963>1.6973) meaning that $\mathrm{H}_{0}$ is supported and $\mathrm{H}_{1}$ is not supported, so that it can be concluded that Ar-Rum variable partially does not affect Income significantly.

c) The effect of t-statistic for Sharia-compliant Bank of Indonesia's Certificate (SBIS) on Sharia Pawnshop's income.

Table 4.6 shows that SBIS variable statistically shows insignificant output with value more than $\alpha(0.006>0.05)$. Meanwhile, $t$-statistic value is -.876 and $\mathrm{t}$-table is $1.6973(\mathrm{df}(\mathrm{n}-\mathrm{k}) 36-6=30, \alpha=0.05)$. Thus, $\mathrm{t}$ statistic $<\mathrm{t}$ table (2.963>1.6973) meaning that $\mathrm{H}_{0}$ is supported and $\mathrm{H}_{1}$ is not supported, so that it can be concluded that SBIS variable partially does not affect Income significantly.

d) The effect of t-statistic for Inflation on Sharia Pawnshop's Income

Table 4.6 shows that Inflation variable statistically shows significant output with value less than $\alpha(0.006<0.05)$. Meanwhile, t-statistic value is 6.721 and $\mathrm{t}$-table is $1.6973(\mathrm{df}(\mathrm{n}-\mathrm{k}) 36-6=30, \alpha=0.05)$. Thus, $\mathrm{t}$ statistic $>\mathrm{t}$ table (6.721>1.6973) meaning that $\mathrm{H}_{0}$ is not supported and $\mathrm{H}_{1}$ is supported, so that it can be concluded that Inflation variable partially affects Income significantly.

e) The effect of t-statistic for BI Rate $n$ on Sharia Pawnshop's Income

Table 4.6 shows that BI Rate variable statistically shows significant output with value less than $\alpha(0.006<0.05)$. Meanwhile, $\mathrm{t}$-statistic value is 4.026 and $\mathrm{t}$-table is $1.6973(\mathrm{df}(\mathrm{n}-\mathrm{k}) 36-6=30, \alpha=0.05)$. Thus, $\mathrm{t}$ statistic $>\mathrm{t}$ table 
(4.026>1.6973)meaning that $\mathrm{H}_{0}$ is not supported and $\mathrm{H}_{1}$ is supported, so that it can be concluded that BI Rate variable partially affects Income significantly.

\section{6) Simultaneous Test (F)}

F test is used to show whether or not all independent variables included into the model have simultaneous effect on dependent or independent variables, or whether or not Mulia, Ar-Rum, SBIS, Inflation, and BI Rate affect significantly Sharia Pawnshop's income. To find out the result of F test, significance level is considered and F statistic is compared with F table to know whether or not those variables affect simultaneously. The result of $\mathrm{F}$ test is presented in table 4.7.

Table 4.7

Simultaneous Test (F)

\begin{tabular}{|c|c|c|c|c|c|c|}
\hline \multicolumn{7}{|c|}{ ANOVAa } \\
\hline & & Sum of Squares & Df & Mean Square & $\mathrm{F}$ & Sig. \\
\hline \multirow{3}{*}{1} & Regression & 24,379 & 5 & 4,876 & 13,772 &, $000 b$ \\
\hline & Residual & 10,621 & 30 & ,354 & & \\
\hline & Total & 35,000 & 35 & & & \\
\hline
\end{tabular}

a. Dependent Variable: Ln_Income

b. Predictors: (Constant), BI_Rate, Ln_Arrum,Ln_Mulia, Ln_SBIS, Inflation

From Table 4.7, it can be seen that F-test is 13.772 at significance level of 0.000. Because significance value is less than $0.000<0.05$, and $\mathrm{F}$ statistic $>\mathrm{F}$ table $(13.772>2.53)$ with F table df: $\alpha,(\mathrm{k}-1),(\mathrm{n}-\mathrm{k})$ or $0.05,(6-1),(36-6)=2.53$. Therefore, it can be concluded that Mulia, Ar-Rum, SBIS, Inflation, and BI Rate variables simultaneously affect Sharia Pawnshop's income significantly.

\section{7) Coefficient of Determinacy Test $\left(\mathbf{R}_{2}\right)$}

Coefficient of Determinacy essentially measures the contribution of independent variable to dependent one. The higher the coefficient of determinacy, the higher is the ability of independent variables (Xs), in this case Mulia, Ar-Rum, 
SBIS, Inflation and BI Rate, in explaining the variance in the dependent variable (Y), Sharia Pawnshop's income.

The coefficient of determinacy $\left(\mathrm{R}_{2}\right)$ value is $0<\mathrm{R}_{2}<1$; thus the more the $\mathrm{R}_{2}$ value, the closer is the relationship between independent and dependent variables. In other words, the model is considered as good. $\mathrm{R}_{2}$ value is close to 1 , meaning that the ability of independent variable in explaining dependent variable is stronger. Otherwise, the closer is the $\mathrm{R}_{2}$ value to 0 , the weak is the ability of independent variable in explaining the fluctuation of dependent variable (Ghozali 2012). $R_{2}=0$ means that the variance of independent variable (Y) cannot be explained by independent variable $(\mathrm{X})$ at all. Meanwhile, $\mathrm{R}_{2}=1$ means that all observed points are on regression line (Nachrowi, 2008).

Coefficient of Determinacy $\left(\mathrm{R}_{2}\right)$ has such weaknesses as biased number of independent variables included into regression model in which each addition of one independent variable and observation number into the model will increase $\mathrm{R}_{2}$ value although the variable included does not affect the dependent variable significantly. To reduce the weakness, coefficient of determinacy $\mathrm{R}_{2}$ ( $\mathrm{R}$ square) used in this study is Adjusted $\mathrm{R}_{2}$ value when evaluating the best regression model. It is because independent variable used in this study is more than one. The Coefficient of Determinacy $\left(\mathrm{R}_{2}\right)$ test result is presented in the table below.

Table 4.8

Coefficient of Determinacy $\left(R_{2}\right)$ Test Model Summaryb

\begin{tabular}{|l|r|r|r|c|}
\hline Model & $\mathrm{R}$ & R Square & \multicolumn{1}{|c|}{$\begin{array}{c}\text { Adjusted R } \\
\text { Square }\end{array}$} & $\begin{array}{c}\text { Std. Error of the } \\
\text { Estimate }\end{array}$ \\
\hline 1 &, $835 \mathrm{a}$ &, 697 &, 646 &, 5950031 \\
\hline
\end{tabular}

a. Predictors: (Constant), BI_Rate, Ln_Arrum, Ln_Mulia, Ln_SBIS, Inflation

b. Dependent Variable: Ln_Income

Source: Result of Data Processing

From table 4.8, it can be seen that coefficient of determinacy ( $\mathrm{R}$ square) value is 0.697 or $6.97 \%$ and Adjusted $\mathrm{R}$ Square is 0.646 or $64.6 \%$, indicating that the effect of Mulia Fund, Ar-Rum, SBIS, Inflation and BI Rate is 64.6\%, while the rest of $35.4 \%(100 \%-64.6 \%)$ is affected by other variables excluded from the 
study. The coefficient of correlation $(\mathrm{R})$ value is 0.835 indicating that the relationship between independent and dependent variables is very strong as it has value more than $0.05(\mathrm{R}>0.05)$ or $0.835>0.05$.

\section{8) Multiple Linear Regression Analysis}

A multiple-linear regression is used to find out the direction of relationship between independent and dependent variables. The regression equation can be seen in table of coefficient test result based on output of SPSS versions 20 on the effect of five independent variables (Mulia, Ar-Rum, SBIS, Inflation and BI Rate) on Sharia Pawnshop's Income. The result of data processing with SPSS 20.0 is presented in the table below.

Table 4.9

Multiple Linear Regression Analysis

Coefficients

\begin{tabular}{|c|c|c|c|c|c|c|c|}
\hline \multirow[t]{2}{*}{ Model } & \multicolumn{2}{|c|}{$\begin{array}{c}\text { Unstandardized } \\
\text { Coefficients }\end{array}$} & \multirow{2}{*}{$\begin{array}{c}\begin{array}{c}\text { Standar } \\
\text { dized } \\
\text { Coeffici } \\
\text { ents }\end{array} \\
\text { Beta }\end{array}$} & \multirow[t]{2}{*}{$T$} & \multirow[t]{2}{*}{ Sig } & \multicolumn{2}{|c|}{$\begin{array}{c}\text { Collinearity } \\
\text { Statistics }\end{array}$} \\
\hline & $B$ & $\begin{array}{l}\text { Std. } \\
\text { Error }\end{array}$ & & & & Tolerance & VIF \\
\hline (constant) & $-2,910 \mathrm{E}-061$ & ,099 & & ,000 & 1,000 & & \\
\hline Ln_Mulia & ,330 & 111 & 330 & 2,063 & ,006 & ,816 & 1,255 \\
\hline Ln_Ar-rum &,- 069 & 142 &,- 069 &,- 487 & ,630 & ,500 & 1,999 \\
\hline Ln_SBIS &,- 166 & 190 &,- 166 &,- 876 & ,388 & 281 & 3,554 \\
\hline Inflation & 974 & 145 & 974 & 6,721 & ,000 & ,482 & 2,076 \\
\hline BI Rate & 1,060 & 263 & 1,060 & 4,026 & ,000 & 146 & 6,847 \\
\hline
\end{tabular}

Coefficientsa

website:http://jurnal.radenfatah.ac.id/index.php/ieconomics 
Dependent Variable of Sharia Pawnshop's Income

Considering the regression equation model shown in table 4.9 , the result of multiple linear regression analysis is as follows:

\section{$-2.910 \mathrm{E}-016 \mathrm{LnY}=\mathrm{a}+0.330 \mathrm{X}_{1}-0.069 \mathrm{X}_{2}-0.166 \mathrm{X}_{3}+0.974 \mathrm{X}_{4}+1.060 \mathrm{X}_{5}$}

Where:

$$
\begin{array}{ll}
\mathrm{LnY} & =\text { Natural Logarithm of Sharia Pawnshop's Income } \\
\mathrm{LnX}_{1} & =\text { Natural Logarithm of Mulia } \\
\mathrm{LnX}_{2} & =\text { Natural Logarithm of Ar-Rum } \\
\mathrm{LnX}_{3} & =\text { Natural Logarithm of Sharia-compliant Bank of } \\
& \text { Indonesia's Certificate } \\
\mathrm{X}_{4} & =\text { Inflation } \\
\mathrm{X}_{5} & =\text { BI Rate }
\end{array}
$$

From the result of hypothesis testing shown in table 4.9 , it can be interpreted that out of 5 variables used, 3 variables (Mulia, Inflation and BI Rate) affect significantly the dependent variables (Sharia Pawnshop's Income). Meanwhile, Ar-Rum and SBIS do not affect dependent variable (Sharia Pawnshop's Income) significantly.

From the multiple-linear equation as shown in table 4.9, it can be seen that the variables that can be included into regression model equation are as follows:

a. Constant value is 2.910E-016, suggesting that if Mulia, Ar-Rum, SBIS, Inflation and BI Rate values equal to 0, Sharia Pawnshop's income value increases by $2.910 \mathrm{E}-016$ units.

b. $\mathrm{X}_{1}$ Mulia value $=0.330$, meaning that each 1 unit increase in $\mathrm{X}_{1}$ Mulia variable will increase Y variable (Sharia Pawnshop's Income) by 0.330 point (unit) ceteris paribus.

c. $\mathrm{X}_{2}$ Ar-Rum value $=-0.069$, meaning that each 1 unit increase in $\mathrm{X}_{2}$ Ar Rum variable will decrease Y variable (Sharia Pawnshop's Income) by -0.069point (unit) ceteris paribus.

d. $\mathrm{X}_{3}$ SBIS value $=-0,166$, meaning that each 1 unit increase in $\mathrm{X}_{3}$ (SBIS) variable will decrease Y variable (Financing Deposit Ratio) by -0.166-point (unit) ceteris paribus.

website:http://jurnal.radenfatah.ac.id/index.php/ieconomics 
e. $\mathrm{X}_{4}$ (Inflation) value $=0.974$, meaning that each 1 unit increase in $\mathrm{X}_{4}$ (Inflation) variable will increase Y variable (Sharia Pawnshop's Income) by 0.974-point (unit) ceteris paribus.

f. $\mathrm{X}_{5}\left(\mathrm{BI}\right.$ Rate) value $=1.060$, meaning that each 1 unit increase in $\mathrm{X}_{4}(\mathrm{BI}$ Rate $)$ variable will increase Y variable (Sharia Pawnshop's Income) by 1.060 point (unit) ceteris paribus.

\section{DISCUSSION}

Considering the result of research above, it can be summarized that three out of five independent variables studied affect while another variable does not affect Sharia Pawnshop's Income. It can be explained below.

\section{1) The Effect of Mulia on Sharia Pawnshop's Income}

From the result of test as shown in table 4.9, it can be seen that Mulia variable has positive beta value. It indicates that Mulia variable has positive and significant effect on Sharia Pawnshop's Income, as it has significance value of 0.006 less than 0.05 and $t$ statistic $>t$ table $(2.963>1.6973)$. It means that $\mathrm{H}_{0}$ is not supported and $\mathrm{H}_{1}$ is supported, so that it can be concluded that Mulia variable affects Sharia Pawnshop's Income.

\section{2) The Effect of Ar Rum on Sharia Pawnshop's Income}

From the result of test as shown in table 4.9, it can be seen that Ar Rum variable has negative beta value. It indicates that Ar Rum variable has negative and insignificant effect on Sharia Pawnshop's Income, as it has significance value of 0.630 more than 0.05 and $\mathrm{t}$ statistic $<\mathrm{t}$ table ($0.487<1.6973)$. It means that $\mathrm{H}_{0}$ is supported and $\mathrm{H}_{1}$ is not supported, so that it can be concluded that Ar Rum variable does not affect Sharia Pawnshop's Income.

\section{3) The Effect of SBIS on Sharia Pawnshop's Income}

From the result of test as shown in table 4.9, it can be seen that SBIS variable has negative beta value. It indicates that SBIS variable has negative and insignificant effect on Sharia Pawnshop's Income, as it has significance value of 0.388 more than 0.05 and $\mathrm{t}$ statistic $<\mathrm{t}$ table $(-0.876<1.6973)$. It means that

website:http://jurnal.radenfatah.ac.id/index.php/ieconomics 
$\mathrm{H}_{0}$ is supported and $\mathrm{H}_{1}$ is not supported, so that it can be concluded that SBIS variable does not affect Sharia Pawnshop's Income.

\section{4) The Effect of Inflation on Sharia Pawnshop's Income}

From the result of test as shown in table 4.9, it can be seen that Inflation variable has positive beta value. It indicates that Inflation variable has positive and significant effect on Sharia Pawnshop's Income, as it has significance value of 0.000 less than 0.05 and $t$ statistic $>t$ table $(6.721>1.6973)$. It means that $\mathrm{H}_{0}$ is not supported and $\mathrm{H}_{1}$ is supported, so that it can be concluded that Inflation variable affects Sharia Pawnshop's Income.

\section{5) The Effect of BI Rate on Sharia Pawnshop's Income}

From the result of test as shown in table 4.9, it can be seen that BI Rate variable has positive beta value. It indicates that BI Rate variable has positive and significant effect on Sharia Pawnshop's Income, as it has significance value of 0.000 less than 0.05 and $t$ statistic $>t$ table (4.026>1.6973). It means that $\mathrm{H}_{0}$ is not supported and $\mathrm{H}_{1}$ is supported, so that it can be concluded that Mulia variable affects Sharia Pawnshop's Income.

Sharia Pawnshop offers a variety of financing product that can be chosen directly by customers according to their need, with easy and quick process. One of them is Mulia finance that can be a safe investment option for bringing the better future into reality. In distributing its finance, Pawnshop also encounters many problems external to the company called external factors. The company should also consider the current economic condition through monetary policy (SBI interest rate), inflation or people's income. The effect of inflation occurs indirectly but through real interest rate with an assumption that if inflation increases, expected profit will increase and finance demand will increase as well. BI's interest rate is a standard of loan and saving interest rate for banks or financial institutions throughout Indonesia. BI rate serves as a signal of BI's monetary policy. Thus, the response of monetary policy is represented in increase, decrease, or constancy of BI Rate. Basically, BI Rate change shows BI's assessment on estimated inflation in the future compared with the inflation target specified.

website:http://jurnal.radenfatah.ac.id/index.php/ieconomics 


\section{CONCLUSION}

Considering the result of data processing in this study, the following conclusions can be drawn. (1) The result of partial (individual) regression test shows significance values of 0.006 for Mulia, 0.000 for inflation, and 0.000 for BI Rate, indicating that those independent variables partially affect dependent variable (Sharia Pawnshop's Income) significantly in Indonesia. In contrast, ArRum variable is insignificant with value of 0.630 and SBIS variables is insignificant with value of 0.388 , indicating that these two variables do not affect Sharia Pawnshop's Income in Indonesia. (2) The result of simultaneous regression test shows that Mulia, Ar-Rum, SBIS, Inflation, and BI Rate variable simultaneously affect Sharia Pawnshop's Income in Indonesia at significance level of 0.000 . However, viewed from previous studies, in addition to factors aforementioned, other factors can also affect Sharia Pawnshop's Income.

\section{REFERENCES}

Antonio, Muhammad Syafi'i. "Bank dari Teori dan Praktek", Penerbit Gema Insani Press: Jakarta, 2001.

Dania Dewi, "Pengaruh Pembiayaan Produktif Pada Pegadaian Syariah Terhadap Peningkatan Pendapatan Nasabah". 2008.

Ghozali, Imam. "Aplikasi Analisis Multivariet dengan Program IBM SPSS 20", Semarang: Universitas Diponogoro, 2012.

Hanudin Amin, Rosita Chong, Hazmi Dahlan, Rostinah Supirah “Ar-Rahnu Shop Acceptance Model (ARSAM)", Malaysia. 2007.

Isnani Ayunia, "Pegadaian Syariah dan Perkembangannya di Indonesia". 2015 Jakarta: Renaisan, 2007.

Kasmir. "Bank dan Lembaga Keuangan Lainnya", Jakarta: PT. Rajawali Press, 2004.

Mulazid, Ade Sofyan. “Kedudukan Sistem Pegadaian”, Edisi Pertama. Penerbit Prenadamedia Group: Jakarta, 2016.

Pandia, Frianto. “Lembaga Keuangan”, Jakarta: Rineka Cipta, 2005.

website:http://jurnal.radenfatah.ac.id/index.php/ieconomics 
Payal Bhatt “Ar-Rahnu (Islamic Powning Broking) Opportunities and Challenges in Malaysia." 2007.

Rais, Sasli. "Pegadaian Syariah; Konsep dan Sistem Operasional", Jakarta: PT. Rajawali Persada, 2010.

Saheed Abdullahi Busari, Sikiru Olanrewaju Aminu. "The Application of A-RahnBased Microcredit Facility as an Alternative Instrument for Poverty Alleviation in Nigeria” 2017.

Siamat, Dahlan. “Menejemen Lembaga Keuangan”, Jakarta: Penerbit FUEI, 2001 Cet. Ke-1.

Soemitra, Andri. “Bank dan Keuangan Syariah”, Jakarta: Kencana, 2009.

Sugiono. "Metode Penelitian Kuantitatif, Kualitatif, dan $R \& D$ ". Alfabeta: Bandung. 2009.

Widiarti dan Sinarti, "Pengaruh Pendapatan, Jumlah Nasabah, dan Tingkat Inflasi Terhadap Penyaluran Kredit Pada Perum Pegadaian Cabang Batam Periode 2008-2012." 2013. 